\author{
Praca poglądowa/Review paper
}

\title{
Rola chirurgii i radioterapii w leczeniu przerzutów raka piersi do mózgu.
}

\section{The role of surgery and radiotherapy in management of breast cancer brain metastases}

\author{
Bartosz Urbański ${ }^{1,2}$ \\ ${ }^{1}$ Katedra i Zakład Elektroradiologii Uniwersytetu Medycznego $w$ Poznaniu, \\ ${ }^{2}$ Oddział Radioterapii i Onkologii Ginekologicznej, Wielkopolskie Centrum Onkologii, Poznań, Polska
}

Celem napisania niniejszej krótkiej pracy jest próba odpowiedzi na pytaniejak odpowiednio dobraćleczenie u chorych z przerzutami raka piersi do mózgu. Jest to niezwykle ważny temat z punktu wiedzenia klinicystów, gdyż dzięki coraz lepszym wynikom leczenia raka piersi i dłuższym czasom przeżycia, obserwujemy więcej przerzutów do OUN. Dane przedstawione w niniejszym artykule zostały zebrane ma podstawie wyników randomizowanych badań z ostatnich kilku lat.

Wśród miejscowych metod leczenia przerzutów raka piersi do mózgu neurochirurgia odgrywa bardzo ważną rolę . Warto wspomnieć o trzech badaniach III fazy w których porównano chirurgiczną resekcję $\mathrm{z}$ następową WBRT (z ang. Whole Brain Radiation Therapy) z samodzielną WBRT ${ }^{1-3}$.

Wyniki badań Patchella i Vechta wykazały wydłużenie czasu całkowitego przeżycia u chorych otrzymujące leczenie skojarzone (mediana 10 vs. 4-6 miesięcy). W badaniu Patchella chorzy, którzy poddani zostali resekcji chirurgicznej mają znacznie mniejsze ryzyko wznowy miejscowej (20\% vs. 52\%) i dłuższy okres funkcjonalnej niezależności. W badaniu Mintza, gdzie dopuszczone były chore z rozsiewem raka również poza ośrodkowym układem nerwowym i w gorszym stanie ogólnym według skali Karnofskiego, nie wykazano zysku z dodania chirurgii do radioterapii całego mózgu. Dlatego zysk z przedłużenia czasu przeżycia po resekcji przerzutowego guza dotyczy wyłącznie podgrupy chorych w dobrym stanie ogólnym oraz z ograniczonym rozsiewem choroby 4 . U odpowiednio dobranych chorych z 2 lub 3 przerzutami w mózgu, którzy są w dobrym stanie neurologicznym i niewielkim rozsiewem poza OUN (ośrodkowym układem nerwowym), całkowita

Adres do korespondencji

Bartosz Urbański

Oddział Radioterapii i Onkologii Ginekologicznej,

Wielkopolskie Centrum Onkologii, ul. Garbary 15, 61-866 Poznań, Polska

Telefon. +48692660261

e-mail: bartosz48@gmail.com 
metastazektomia zmian w mózgu daje takie same wyniki jak u chorych z tylko jednym przerzutem w OUN5. Jednym z ograniczeń tych badań jest to, że do analizy włączani byli chorzy z różnymi rozpoznaniami histopatologicznymi, ze względnie małym odsetkiem chorych z przerzutami raka piersi (zazwyczaj 10\% - 20\%). Dlatego też zalecenia postępowania w przerzutach do OUN są do pewnego stopnia ekstrapolacją rezultatów badań nad chorymi z pierwotnym niedrobnokomórkowym rakiem płuca.

Dla większości pacjentów chirurgiczna resekcja pozwala na natychmiastowe uśmierzenie objawów ciasnoty wewnątrzczaszkowej, zmniejszenie zaburzeń ogniskowych oraz częstości napadów padaczkowych. Radykalna makroskopowo resekcja może być obecnie przeprowadzona z relatywnie niską śmiertelnością dzięki zastosowaniu okołooperacyjnego, funkcjonalnego rezonansu magnetycznego, śródoperacyjnej neuronawigacji i mapowania korowego ${ }^{6}$. Za pomocą wczesnego, pooperacyjnego rezonansu magnetycznego można wykryć u około 20\% guz resztkowy, co jest związane ze zwiększonym ryzykiem wznowy miejscowej7.

W ostatnich latach intensywnie badano wpływ technik operacyjnych na odsetek powikłań i wyniki funkcjonalne oraz na ryzyko wznowy miejscowej u chorych $\mathrm{z}$ pojedynczym ogniskiem przerzutowym w mózgu. Ilość pooperacyjnych powikłań nie zależy od resekcji „en bloc” w porównaniu do wycięcia w kilku fragmentach tkankowych w obszarach mózgowia odpowiedzialnych za inteligencję lub przy wielkich guzach ${ }^{8}$. Rozsiew nowotworu wzdłuż opon mózgowo-rdzeniowych może być powikłaniem leczenia, gdzie neurochirurg podczas operacji rozfragmentował guz, zwłaszcza u chorych z przerzutami w obrębie tylnego dołu czaszki (13.8\% vs. 5\%-6\%) 9

Wreszcie, chirurgia jest ważna w leczeniu miejscowym przerzutów raka piersi do mózgu, ponieważ umożliwia badania molekularne wyciętej tkanki, która może się znacznie różnić od ogniska pierwotnego.. Jest to niezbędne, aby indywidualnie dopasować terapie molekularne ukierunkowane na specyficzne mutacje i enzymy w przerzutowej tkance.

Pomimo wyników płynących z randomizownaego badania Patchella $10 \mathrm{w}$ którym udowodniono lepsze wyniki leczenia (mniejsze ryzyko wznowy miejscowej oraz mniejsze ryzyko zgonu z powodu powikłań neurologicznych) u chorych $\mathrm{z}$ pojedynczym przerzutem poddanych metastazektomii i uzupełniającej radioterapii całego mózgowia w porównaniu do tych, którzy mieli tylko zabieg chirurgiczny, jest sporo kontrowersji w odniesieniu do roli radioterapii w tym badaniu. To doprowadziło do skonstruowania badania N107C/CEC.3 gdzie losowo dobierano technikę radioterapii uzupełniającej u chorych po zabiegu neurochirurgicznym (WBRT vs SRT - Stereotactive Radiation Therapy). SRS na pozostawione zmiany była dozwolona w obu grupach. Badana grupa została podzielona w zależności od miejsca zmiany pierwotnej oraz opornych na radioterapię odmian histologicznych. To badanie zostało zaprezentowane podczas rocznego spotkania Amerykańskiego Towarzystwa Radioterapii Onkologicznej ASTRO w 2016 roku, ale nie zostało jeszcze opublikowane ${ }^{11}$. W wynikach pracy nie zauważono różnicy w czasie całkowitego przeżycia (11-12 miesięcy), bez różnicy w odniesieniu do wieku, zajęcia narządów pozaczaszkowych, liczby przerzutów w mózgu, histologii oraz wielkości loży pooperacyjnej. Jakkolwiek wykazano małą, ale statystycznie istotną różnicę w wynikach funkcjonalnych działania mózgu na korzyść SRS (2.8 miesiąca bez ubytków neurologicznych u chorych z WBRT vs. 3.3 z SRS; p < 0.0001). Tylko 5,4\% chorych z WBRT nie miało ubytków poznawczych po 6 miesiącach w przeciwieństwie do $22.9 \%$ chorych w ramieniu z SRS.

W literaturze istnieje kilka badań gdzie porównano wyniki SRS z i bez dodania WBRT ${ }^{12-14}$. Jednym z nich było badanie z losowym doborem chorych opublikowane przez Ayoama 12 w 2006 roku. Zrandomizowano w nim 132 chorych z liczbą przerzutów 1-4 odpowiednich do SRS. Pierwszorzędowym punktem końcowym był czas całkowitego przeżycia, a drugorzędowymi: ryzyko wznowy miejscowej, liczba terapii ratujących, zachowanie funkcji neurologicznych, toksyczność i przyczyna śmierci. Badanie zostało przedwcześnie zamknięte po analizie wyników, gdzie zorientowano się, że aby wykazać statystycznie istotną różnicę w czasie przeżycia całkowitego potrzeba ponad 800 chorych. Przerzutowy rak piersi stanowił zaledwie $7 \%$ włączonych chorych, większość stanowili chorzy z rakiem niedrobnokomórkowym płuca. W ramieniu z SRS średni czas całkowitego przeżycia nie różnił się od ramienia z WBRT. Zauważono, że grupa otrzymująca 
leczenie skojarzone z SRS oraz WBRT ma mniejsze ryzyko wewnątrzczaszkowej wznowy miejscowej po 1 roku obserwacji (47\% vs. 77\%; p < 0.001) i wymaga rzadziej leczenia ratującego w przeciwieństwie do grupy badanej z samodzielną SRS.

Inne duże badanie na 359 chorych, z czego 12\% z rakiem piersi z 1-4 przerzutów w mózgu, losowo przydzielono do grup leczonych neurochirurgicznie lub SRS z lub bez WBRT15. Czas całkowitego przeżycia był podobny w obu grupach $(\mathrm{p}=0.89)$, chociaż ryzyko wznowy miejscowej było wyższe w ramieniu $\mathrm{z}$ wyłączną chirurgią/SRS niż po uzupełnieniu radioterapią WBRT.

Metaanaliza z 2015 roku Saghala 16 wykazała, że pacjenci w wieku 50 lat i młodsi mają istotnie statystycznie dłuższy czas przeżycia ( $\mathrm{p}=0.04$ ) Kidy zastosowano SRS. Wyniki były podobne niezależnie do tego, czy przerzuty w OUN pochodziły z raka piersi czy płuca.

Podsumowując nie można jednoznacznie określić jaka sekwencja leczenia będzie najlepsza dla chorych z przerzutami do OUN. Korzystnymi prognostycznie cechami jest niewielka liczba przerzutów, młody wiek oraz dobry stan ogólny. Warto pomyśleć o radioterapii u chorych po metastazektomii, których prognozowany czas przeżycia jest dłuższy niż 3 m-ce. Potrzeba jednak kolejnych, dobrze zaprojektowanych badań, aby wyjaśnić kwestie, na które dzisiaj nie potrafimy udzielić odpowiedzi.

\section{Piśmiennictwo / References}

[1] Patchell RA, Tibbs PA, Walsh JW, et al. A randomized trial of surgery in the treatment of single metastases to the brain. $N$ Engl $J$ Med. 1990;322:494-500.

[2] Vecht CJ, Haaxma-Reiche H, Noordijk EM, et al. Treatment of single brain metastasis: radiotherapy alone or combined with neurosurgery? Ann Neurol. 1993;33:583-590.

[3] Mintz AH, Kestle J, Rathbone MP, et al. A randomized trial to assess the efficacy of surgery in addition to radiotherapy in patients with a single cerebral metastasis. Cancer. 1996;78:1470-1476.

[4] Soffietti R, Abacioglu U, Baumert B. Diagnosis and treatment of brain metastases from solid tumors: guidelines from the European Association of Neuro-Oncology (EANO). Neuro-oncol. 2017. In press.

[5] Pollock BE, Brown PD, Foote RL, et al. Properly selected patients with multiple brain metastases may benefit from aggressive treatment of their intracranial disease. $J$ Neurooncol. 2003;61:73-80.

[6] Vogelbaum MA, Suh JH. Resectable brain metastases. J Clin Oncol. 2006;24:1289-1294.

[7] Kamp MA, Rapp M, Bühner J, et al. Early postoperative magnet resonance tomography after resection of cerebral metastases. Acta Neurochir (Wien). 2015;157:1573-1580.

[8] Patel AJ, Suki D, Hatiboglu MA, et al. Impact of surgical methodology on the complication rate and functional outcome of patients with a single brain metastasis. $J$ Neurosurg. 2015;122:1132-1143.

[9] Suki D, Abouassi H, Patel AJ, et al. Comparative risk of leptomeningeal disease after resection or stereotactic radiosurgery for solid tumor metastasis to the posterior fossa. $J$ Neurosurg. 2008;108:248257.

[10] Patchell RA, Tibbs PA, Regine WF, et al. Postoperative radiotherapy in the treatment of single metastases to the brain: a randomized trial. JAMA. 1998;280:1485-1489.

[11] Brown PD, Ballman KV, Cerhan J, et al. N107C/CEC.3: A phase III trial of post-operative stereotactic radiosurgery (SRS) compared with whole brain radiotherapy (WBRT) for resected metastatic brain disease (LBA-1). Int J Radiat Oncol Biol Phys. 2016;96:937.

[12] Aoyama H, Shirato H, Tago M, et al. Stereotactic radiosurgery plus wholebrain radiation therapy vs stereotactic radiosurgery alone for treatment of brain metastases: a randomized controlled trial. JAMA. 2006;295:2483-2491. Chang EL, Wefel JS, Hess KR, et al. Neurocognition in patients with brain metastases treated with radiosurgery or radiosurgery plus whole-brain irradiation: a randomised controlled trial. Lancet Oncol. 2009;10:1037-1044.

[13] Soffietti R, Kocher M, Abacioglu UM, et al. A European Organisation for Research and Treatment of Cancer phase III trial of adjuvant whole-brain radiotherapy versus observation in patients with one to 
three brain metastases from solid tumors after surgical resection or radiosurgery: quality-of-life results. J Clin Oncol. 2013;31:65-72.

[14] Kocher M, Soffietti R, Abacioglu U, et al. Adjuvant whole-brain radiotherapy versus observation after radiosurgery or surgical resection of one to three cerebral metastases: results of the EORTC 2295226001 study. J Clin Oncol. 2011;29:134-141.

[15] Sahgal A, Aoyama H, Kocher M, et al. Phase 3 trials of stereotactic radiosurgery with or without wholebrain radiation therapy for 1 to 4 brain metastases: individual patient data meta-analysis. Int $J$ Radiat Oncol Biol Phys. 2015;91:710-717. 